Article

\title{
Nutritional Value of Whole Maize Kernels from Diverse Endosperm Types and Effects on Rheological Quality
}

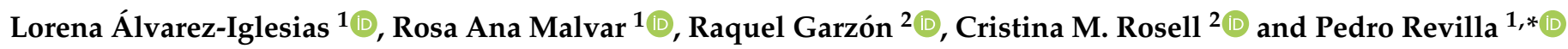 \\ 1 Misión Biológica de Galicia (CSIC), 36080 Pontevedra, Spain; lalvarez@mbg.csic.es (L.Á.-I.); \\ rmalvar@mbg.csic.es (R.A.M.) \\ 2 Institute of Agrochemistry and Food Technology (IATA-CSIC), 46980 Valencia, Spain; \\ r.garzon@iata.csic.es (R.G.); crosell@iata.csic.es (C.M.R.) \\ * Correspondence: previlla@mbg.csic.es; Tel.: +34-986854800; Fax: +34-986841362
}

Citation: Álvarez-Iglesias, L.; Malvar, R.A.; Garzón, R.; Rosell, C.M.; Revilla, P. Nutritional Value of Whole Maize Kernels from Diverse Endosperm Types and Effects on Rheological Quality. Agronomy 2021, 11, 2509. https://doi.org/10.3390/ agronomy11122509

Received: 11 November 2021 Accepted: 9 December 2021 Published: 10 December 2021

Publisher's Note: MDPI stays neutral with regard to jurisdictional claims in published maps and institutional affiliations.

Copyright: (c) 2021 by the authors. Licensee MDPI, Basel, Switzerland. This article is an open access article distributed under the terms and conditions of the Creative Commons Attribution (CC BY) license (https:// creativecommons.org/licenses/by/ $4.0 /)$.

\begin{abstract}
Maize's (Zea mays L.) nutrient content can be modified through selection. The objective of this study was to assess the nutritive value of 13 maize hybrids from four endosperm types, and the relationship between nutrient concentration, agronomic and rheological value. The hybrids were evaluated in two locations of Northwestern Spain over two years. There was genetic diversity among endosperm types and genotypes for all nutrients, with significant environmental effects, but few genotype $\times$ environment interactions. Flint hybrids had the highest protein and lipid content. The mutant $w x 1$ significantly increased protein and reduced lipid, and both $w x 1$ and $o 2$ reduced ash and starch content and increased total fiber. Variability among hybrids within the $w x 1$ endosperm was significant for most nutrients. Correlations between nutrients were rarely significant, implying that protein and lipid can be improved independently. Protein and lipid were negatively correlated with grain yield and plant height. However, improving nutrient content could alter agronomic performance, as nutrients had significant negative effects on rheological factors, particularly protein and lipid, which had negative effects on whole meal and on bread characteristics. Therefore, nutrient content can be improved in maize, but negative effects on agronomic and quality have to be taken into account.
\end{abstract}

Keywords: nutritional value; maize; endosperm; flint grain; dent grain; opaque2; waxy1; rheological factors

\section{Introduction}

Maize (Zea mays L.) is one of the main crops worldwide, and a model species for breeding and genetics [1]. The European leader of maize production is France, which exports it for a value higher than $\$ 1600$ million (https: / / www.mccormick.it/es/todos-losdatos-actualizados-sobre-la-produccion-de-maiz-en-el-mundo/ (accessed on 10 November 2021)). On the other hand, maize cultivated area is decreasing in Spain due to the low prices of maize for feed and forage. In the country in 2020, 90.646 ha were sown with maize for foraging and 356.278 ha for grain production (https: / / www.mapa.gob.es / es / estadistica/temas / estadisticas-agrarias / totalespanayccaa2020_tcm30-553610.pdf (accessed on 10 November 2021)). Today, maize cultivation area is around $4 \%$ of the total cultivated area in Spain, with a deficit of more than 6.5 million of $\mathrm{Mg}$. Spain imports maize for an average annual value of 2000 million dollars, mainly from importation from non-European countries. The main reason for the Spanish commercial deficit in maize production could be that the price of cereal production is higher than in many countries that have less strict regulations of safety and security and labor costs than in Spain, or Europe at large. The introduction of quality maize with high added value could palliate this progressive reduction of the profitability of maize production and agriculture.

The large genetic variability of maize allows large diversity of uses and values, as maize is appropriate for manufacturing gluten-free bakery products for celiac patients [2,3]. 
Previous reports have shown that diversity among maize varieties was not significant for specific volume or for dough behavior during mixing and handling, but traditional maize populations reached higher qualifications in sensory analyses than commercial hybrids $[2,4,5]$. Genetic variability among maize populations from different origins and endosperm types has been reported for agronomic and rheological quality traits $[5,6]$, and a large collection of Italian populations characterized by NIRS for nutrient content [7] showed large variability and a couple of Italian flint landraces (Nostrano dell'Isola and Marano) with high protein, lipid and carotenoids. Nevertheless, their performance in food applications like breadmaking potential is not included in breeding programs.

Several natural mutants have been identified that can increase the nutritive value of maize varieties, such as high amylopectin (waxy1) and high-quality protein (opaque2) maize mutants [8]. The mutant waxy1 (wx1), located on chromosome 9, is used for high energy diets [9] because it produces highly digestible starch, and waxy 1 contains only starch in the form of amylopectin. This highly branched starch increases viscosity and digestibility [10]. Furthermore, waxy1 maize is used in frozen food processing and livestock feeding industries, as well as in textile, adhesive and paper industries [11]. The mutant opaque2 (o2) increases protein quality, though not protein quantity, and reduces yield and agronomic performance [12-14]. The available varieties with wxy and $o 2$ mutants and their respective isogenic hybrids have dent kernels, while maize used for bread is made with flint kernels.

The objectives of this study were to assess: (1) the nutritive value of maize genotypes from four endosperm types (dent, flint, and waxy and opaque mutants) of maize; and (2) the relationship between their nutrient concentration and agronomic and rheological values.

\section{Materials and Methods}

\subsection{Maize Varieties and Field Trials}

Thirteen flint or dent-kernel maize hybrids, along with near-isogenic maize hybrids for high amylopectin (waxy1) or high-quality protein (opaque2), were used for assessing the effects of endosperm type and modified maize starch or protein on nutrient content (Table 1). Three waxy1 maize hybrids and their respective wild type (Wx1) hybrids, two opaque2 hybrids and their respective dent wild type (O2) hybrids and three unrelated flint hybrids were evaluated (Table 1). The hybrids previously developed in [8] were evaluated in 2016 and 2017 in Pontevedra $\left(42^{\circ} 24^{\prime} \mathrm{N}, 8^{\circ} 38^{\prime} \mathrm{W}\right.$ and $20 \mathrm{~m}$ above sea level) and Barrantes $\left(42^{\circ} 30^{\prime} \mathrm{N}, 8^{\circ} 46^{\prime} \mathrm{W}\right.$ and $50 \mathrm{~m}$ above sea level). Both locations are in northwestern Spain, and have cool and wet springs and a short growth period. The experimental design was a randomized complete block design with two repetitions. Four-row plots were used in order to minimize the xenia effect in the two central rows. Rows were spaced $80 \mathrm{~cm}$, and each row consisted of 13 hills per row spaced $21 \mathrm{~cm}$, given an approximate plant density of 60,000 plants ha ${ }^{-1}$. Trials were sown on April 16 of 2016 and April 25 of 2017 in Pontevedra, and on May 15 of 2016 and 22 of 2017 in Barrantes (northwestern Spain).

\subsection{Kernel Nutritional Characteristics and Quality Parameters}

Near-infrared reflectance (NIR) spectroscopy analysis of grain samples was made on a per-plot basis using the bulked grain of ears from the two central rows of the four-row plot, in order to minimize the xenia effect. Samples from each plot were maintained in a seed storage chamber until grain moisture was stabilized at around $13 \%$. The spectral information of samples was obtained using a NIRS DS2500 analyzer (FOSS NIR Systems, Hilleroed, Denmark) with a scanned range of 400-2500 nm. Values for protein, lipid, starch, ash and total fiber were reported as percentage of grain at $13 \%$ moisture content. 
Table 1. Maize hybrids, with Dent grains homozygous for recessive mutants with high amylopectin (waxy1, wx1) or quality protein (opaque2,o2) and the respective wild-type isogenic hybrids, evaluated during two years in two locations of Pontevedra (Northwestern Spain), along with three Flint hybrids, for grain, flour and bread quality.

\begin{tabular}{cc}
\hline Hybrid & Allele \\
\hline A632 $\times$ C103 & $w x 1$ \\
\cline { 2 - 2 } B37 $\times$ C103 & $W x 1$ \\
\cline { 2 - 2 } B37 $\times$ Oh43 & $w x 1$ \\
\hline A619 $\times$ A632 & $W x 1$ \\
\hline B37 $\times$ Mo17 & $w x 1$ \\
\hline EA2087 $\times$ PB97 & $W x 1$ \\
\hline EP1 $\times$ EP42 & O2 \\
\hline EP42 $\times$ EP39 & o2 \\
\hline
\end{tabular}

We used agronomic traits and rheological parameters previously published [8] for finding relationships with the nutrients calculated here. Quality parameters were previously described [8]. Briefly, maize kernels were milled by using a laboratory mill (IKA M20 Labortechnik, Staufen, Germany), and the meal was sieved through $0.85 \mathrm{~mm}$ screen. Pasting properties were assessed with a Rapid Visco Analyser (RVA 4500, Perten Instruments SA, Stockholm, Sweden). The sample was dispersed in distilled water, and the apparent viscosity of flours was recorded along the heating-cooling cycle using Thermocline software for Windows (Perten Instruments SA, Stockholm, Sweden). We determined onset temperature, maximum viscosity at $95{ }^{\circ} \mathrm{C}$, and the trough, breakdown, final viscosity total setback and area under the apparent viscosity curve were evaluated. Water hydration capacity was calculated. For bread making, doughs were mixed in a stirrer with a turbine accessory (IKA Eurostar 40, Staufen, Germany) (Figure 1). Crumb bread color was determined by using a colorimeter (Chroma meter CR-400/410, Konica Minolta, Tokyo, Japan) after standardization, using CIE- $L^{*} a^{*} b^{*}$ uniform color space, where $L^{*}$ indicates lightness, $a^{*}$ indicates hue on a green $(-)$ to red $(+)$ axis, and $b^{*}$ indicates a hue on a blue $(-)$ to yellow $(+)$ axis. The force required to compress bread crumb was determined in a Texture Analyzer TA-XT2i (Stable Micro Systems, Surrey, UK). The parameters recorded were hardness, retarded recovered elasticity, cohesiveness, chewiness and instant recovery speed.

\subsection{Statistical Analyses}

Analyses of variance combined over environments and individual analyses of variance for each environment were made with hybrids as fixed factors and all other sources of variation as random factors. Means comparison of hybrids and endosperms types were performed with the Fisher's protected LSD test. Correlation analyses were made among the means of nutrient components, and also between each nutrition trait and the agronomic traits reported [8]. In order to identify the nutrients that were significant covariates on rheological parameters, multiple regressions analyses using the stepwise selection method ( $p=0.05)$ were carried out by using the means of each rheological trait reported by Revilla et al. [8] as a dependent variable and nutrients' composition as independent variables. All statistical analyses were conducted with a Statistical Analysis System (The SAS Institute: Cary, NC, USA) [15]. 


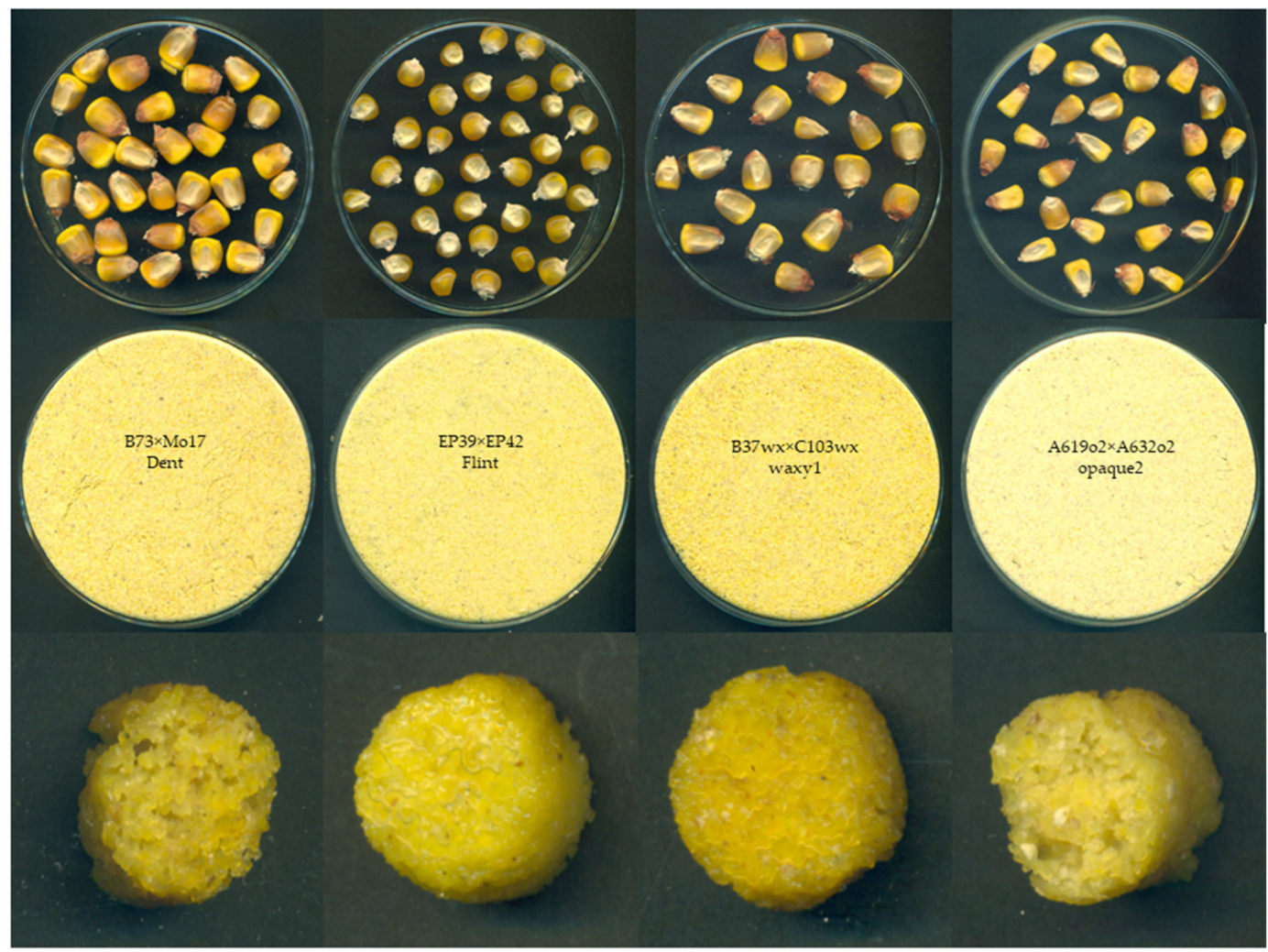

Figure 1. Grain, flour and bread from four maize hybrids representative of the dent, flint, waxy1 and opaque2 endosperm types.

\section{Results}

\subsection{Analyses of Variance and Comparisons of Means}

Significant effects of environment, endosperm and genotype were detected for all nutrients (Supplementary Table S1). Only the endosperm type $\times$ genotype for protein content and the environment $\times$ endosperm type $\times$ genotype interactions were significant for ash; and they were mainly of magnitude, rather than rank (Supplementary Table S1). As expected, the most abundant nutrient was starch, followed by protein and lipid, while total fiber was low and the lowest component was ash (Table 2, Figure 2). Among the 13 hybrids evaluated here, the range of variability was largest for total fiber, followed by protein content, and lowest for starch (Table 2).

Flint hybrids had the highest protein and dent hybrids had the lowest protein (Table 2, Figure 2). Differences between the 02 hybrids and their wild type isogenic hybrids were not significant for protein; however, the recessive mutant $w x 1$ increased protein in A632wx $\times$ C103wx respect to the wild type A632 $\times$ C103. Proportion of lipid was highest for the flint hybrids and lowest for the $w x 1$ and some of the dent hybrids. The 02 mutant had no significant effects on lipid, and $w x 1$ reduced the proportion of lipid in B37wx $\times$ C103wx, respect to its wild isogenic hybrid. The proportion of ash was highest for $w x 1$ and $o 2$ hybrids and lowest for dent hybrids, and both mutants significantly increased the proportion of ash respect to their wild type hybrids. Conversely, the proportion of starch was lowest for $w \times 1$ and $o 2$ hybrids, and highest for flint and dent hybrids, and both mutants significantly decreased the proportion of starch respect to their wild type hybrids. Finally, total fiber was highest for 02 and some $w x 1$ hybrids, and lowest for flint and some dent hybrids; the $o 2$ mutant significantly increased total fiber, while wx1 significantly increased total fiber, except in B37wx $\times$ C103wx. 
Table 2. Mean ${ }^{\alpha}$ percentage, on a wet weight basis (13\% grain moisture content), of nutrients in maize hybrids with high amylopectin (waxy1) or protein (opaque2), and dent or flint kernel and in the four endosperms types evaluated during two years in two locations of Pontevedra (Northwestern Spain).

\begin{tabular}{|c|c|c|c|c|c|}
\hline Genotype & Protein & Lipid & Ash & Starch & Total Fiber \\
\hline \multicolumn{6}{|c|}{ Mean percentage in maize hybrids } \\
\hline $\mathrm{A} 619 \mathrm{o} 2 \times \mathrm{A} 632 \mathrm{o} 2$ & 7.65 def & $3.57^{\mathrm{cd}}$ & $1.64^{\mathrm{ab}}$ & 61.30 ef & $2.81^{\mathrm{a}}$ \\
\hline $\mathrm{A} 619 \times \mathrm{A} 632$ & 7.82 cde & $3.43 \mathrm{def}$ & $1.36^{\mathrm{de}}$ & $63.34^{a b}$ & $2.14^{\text {cde }}$ \\
\hline $\mathrm{A} 632 \mathrm{wx} \times \mathrm{C} 103 \mathrm{wx}$ & $9.22^{b}$ & 3.31 ef & $1.56^{\mathrm{bc}}$ & $60.76^{f}$ & $2.33^{\mathrm{cd}}$ \\
\hline $\mathrm{A} 632 \times \mathrm{C} 103$ & $6.96^{f}$ & 3.32 ef & $1.28^{\mathrm{e}}$ & $63.85^{a}$ & $1.94^{\mathrm{e}}$ \\
\hline B37o2 × Mo17o2 & $8.25^{\text {cde }}$ & $3.45^{\text {cdef }}$ & $1.53^{c}$ & 61.32 ef & $2.78^{a}$ \\
\hline $\mathrm{B} 37 \mathrm{wx} \times \mathrm{C} 103 \mathrm{wx}$ & $8.48^{\text {cde }}$ & $3.28^{\mathrm{f}}$ & $1.66^{\mathrm{a}}$ & $59.46^{\mathrm{g}}$ & $2.87^{\mathrm{a}}$ \\
\hline B37wx $\times$ Oh43wx & $8.03^{\text {cde }}$ & $3.32^{\text {ef }}$ & $1.56^{\mathrm{bc}}$ & 61.09 ef & $2.61^{a b}$ \\
\hline B37 × C103 & $7.65^{\text {edef }}$ & $3.60^{\mathrm{cd}}$ & $1.41^{\mathrm{d}}$ & $62.38^{\mathrm{cd}}$ & $2.62^{a b}$ \\
\hline $\mathrm{B} 37 \times \mathrm{Mo17}$ & 7.80 cde & 3.51 cde & $1.33^{\mathrm{de}}$ & $62.74^{\mathrm{bc}}$ & $2.39 \mathrm{bc}$ \\
\hline $\mathrm{B} 37 \times \mathrm{Oh} 43$ & 7.33 ef & $3.45^{\text {cdef }}$ & $1.41^{\mathrm{d}}$ & $62.78^{b c}$ & $2.32^{\mathrm{cd}}$ \\
\hline EA2087 × PB97 & $8.46^{\text {cde }}$ & $4.21^{\mathrm{b}}$ & $1.33^{\mathrm{de}}$ & $63.17 \mathrm{abc}$ & 2.12 cde \\
\hline $\mathrm{EP} 1 \times \mathrm{EP} 42$ & $9.77^{a b}$ & $3.64^{c}$ & $1.40^{\mathrm{d}}$ & $64.03^{a}$ & $2.05^{d e}$ \\
\hline EP42 $\times$ EP39 & $10.16^{\mathrm{a}}$ & $4.48^{\mathrm{a}}$ & $1.52^{\mathrm{c}}$ & $61.71^{\mathrm{de}}$ & $1.88^{\mathrm{e}}$ \\
\hline LSD (0.05) & 0.69 & & 0.10 & 0.87 & 0.28 \\
\hline \multicolumn{6}{|c|}{ Mean percentage in endosperm types } \\
\hline Dent & $7.48^{\mathrm{d}}$ & $3.46^{b}$ & $1.36^{\mathrm{c}}$ & $62.98^{a}$ & $2.30^{\mathrm{c}}$ \\
\hline Flint & $9.46^{\mathrm{a}}$ & $4.11^{\mathrm{a}}$ & $1.42^{b}$ & $62.97^{\mathrm{a}}$ & $2.02^{d}$ \\
\hline Opaque2 & $8.05^{c}$ & $3.49^{b}$ & $1.57^{\mathrm{a}}$ & $61.31^{b}$ & $2.79^{\mathrm{a}}$ \\
\hline Waxy1 & $8.58^{b}$ & $3.30^{c}$ & $1.59^{\mathrm{a}}$ & $60.44^{c}$ & $2.60^{b}$ \\
\hline LSD (0.05) & 0.40 & 0.12 & 0.06 & 0.51 & 0.16 \\
\hline
\end{tabular}

${ }^{\alpha}$ Means followed by the same letter, within the same column and category, are not significantly different according to the Fisher's protected LSD at $p=0.05$.

Variability for percentage of nutrients was significant among genotypes within endosperm types for most traits, except in 02 (Table 2). Dent hybrids, which had the lowest protein, were not significantly different for protein (Supplementary Table S2); however, hybrids involving the Reid inbred B73 had the highest lipid content, while hybrids with the Reid inbred A632 had the highest fiber content. Flint hybrids were not significantly different for fiber, and had no clear patterns of variability for the other nutrients. The wx 1 hybrids, with the lowest lipid content, were not significantly different for lipid, and did not follow clear patterns of diversity for the other nutrients. Finally, $o 2$ hybrids were not significantly different for any nutrient, except for ash. Differences among genotypes were significant for all flour traits and for most bread traits, except retarded recovery elasticity [8]. 


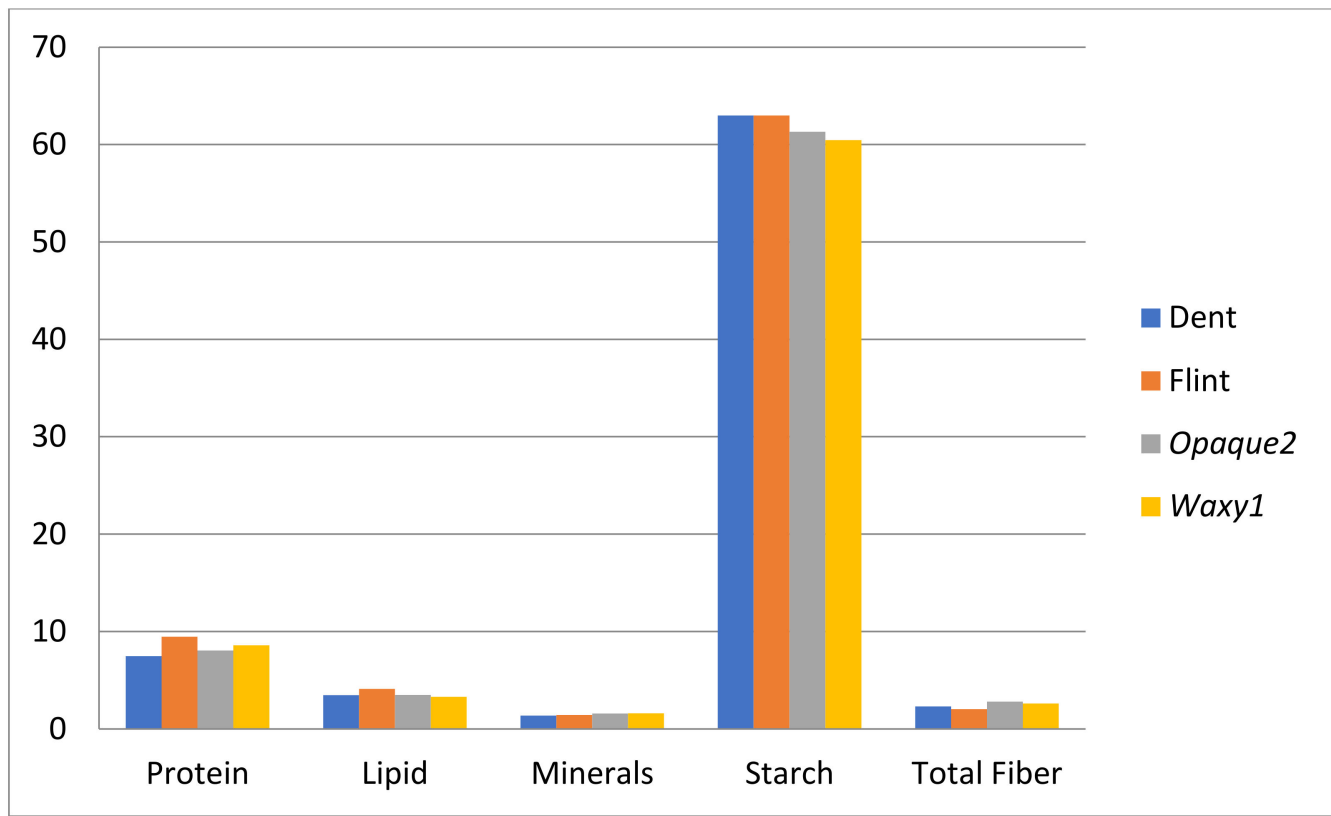

Figure 2. Percentage of nutrients (protein, lipid, ash, starch, and total fiber) in grain of four maize endosperm types (dent, flint, opaque 2 and waxy1).

\subsection{Correlations between Nutrition Traits}

Most correlation coefficients between nutrients were not significant; indeed, the only significant positive correlation was found between ash and total fiber, while the correlation was negative between ash and starch and between total fiber and starch (data not shown).

Most correlations between nutrients and the agronomic traits published previously [8] were not significant; however, grain yield and plant height had significant negative correlations with protein and lipid, days to pollen or silking had also a negative correlation with lipid, as well as early vigor with ash. Other negative correlations were found between emergence and total fiber, as well as early vigor with ash and total fiber. Conversely, early vigor had positive correlation with starch and days to silking with total fiber. Therefore, increasing protein or lipid could reduce yield or biomass (plant height); furthermore, increasing lipid would delay flowering time.

\subsection{Regressions of Nutrition and Bread Making Traits}

Protein was the nutrient with most significant effects on rheological traits, followed by starch and lipid. Conversely, the rheological traits that were more affected by nutrients were Onset pasting temperature (Cumulated $\left.\mathrm{R}^{2}=0.95\right), \mathrm{WBC}\left(\right.$ Cumulated $\left.\mathrm{R}^{2}=0.85\right)$, and Crumb color $L^{*}$ (Cumulated $\mathrm{R}^{2}=0.71$ ), while Breakdown and Crumb color $b^{*}$ were not affected by nutrient contents.

Most of the significant effects were found in whole meal traits rather than in bread traits. Protein and lipid had negative effects on most of the traits, while starch and total fiber had positive effects. Proteins increase on set pasting temperature $\left(b=1.56, R^{2}=0.10\right)$ and crumb color $L^{*}\left(b=1.07, R^{2}=0.26\right)$, while reducing maximum viscosity $(b=-226.2$, $\left.R^{2}=0.41\right)$, trough $\left(b=-186.2, R^{2}=0.53\right)$, area under the curve $\left(b=-1521.7, R^{2}=0.39\right)$, chewiness $\left(b=-3.70, R^{2}=0.33\right)$ and instant recovery speed $\left(b=-0.007, R^{2}=0.26\right)$. Lipids increase on set pasting temperature $\left(b=5.39, R^{2}=0.81\right)$, while decreasing water binding capacity $\left(b=-12.34, R^{2}=0.50\right)$, crumb color $a^{*}\left(b=-1.16, R^{2}=0.23\right)$ and cohesiveness $\left(b=-0.09, R^{2}=0.48\right)$. Ash increases crumb color $L^{*}\left(b=22.01, R^{2}=0.22\right)$ and decreases water binding capacity $\left(b=-31.04, R^{2}=0.04\right)$. Starch increases on set pasting temperature $\left(b=0.54, R^{2}=0.04\right)$, final viscosity $\left(b=366.3, R^{2}=0.40\right)$, total setback $\left(b=207.9, R^{2}=0.60\right)$, crumb color $L^{*}\left(b=2.65, R^{2}=0.23\right)$ and hardness $\left(b=16.7, R^{2}=0.28\right)$, while decreasing 
water binding capacity $\left(b=-5.92, R^{2}=0.31\right)$. Finally, total fiber increases final viscosity $\left(b=844.8, R^{2}=0.20\right)$ and hardness $\left(b=45.2, R^{2}=0.25\right)$.

\section{Discussion}

We found significant diversity for all nutrients and some significant interactions between nutrient content and endosperm types, as well as with environment. Genotype $\times$ environment interactions were of rank, indicating that differences among genotypes for nutrient content were stable enough across environments for allowing successful breeding programs focusing on modifying the nutrient composition of maize. The most abundant nutrient in maize grain is starch, and the range of variability was the lowest for this nutrient. We found the highest range of variability for the nutrients with the lowest content. The mean values of protein and lipid found in this set of hybrids were lower than those of previous reports for European landraces, and the percentage of starch was higher in the current set of hybrids [7,16,17]; for example, Alves et al. [16] reported $11 \%$ mean protein, $4.97 \%$ mean lipid and $2.16 \%$ mean fiber content. The ranges detected here for nutrients were narrower than those reported in previous reports of landraces, as expected, given that biodiversity was larger in the germplasm collections than in this set of hybrids. For example, the Italian germplasm collection has between 6.31 and $14.81 \%$ crude protein, 2.53 and $18.52 \%$ crude lipid, and 58.55 to $73.09 \%$ starch on a dry basis.

Protein and lipid content were highest in flint hybrids, which is the endosperm type preferred for maize bread. The recessive mutant $w x 1$ increased protein in some genotypes, reduced lipids in other genotypes, and increased ash and fiber, while reducing starch. The recessive mutant 02 increased ash and fiber and reduced starch. Similarly, Dado and Beek [18] found that $o 2$ had lower starch content that the wild type hybrids. Therefore, the effects of modifying starch or protein on other nutrients depend on the genotype, which means that there are gene $\times$ genotype interactions.

Differences among genotypes within endosperm types were generally significant for nutrients, except in $o 2$, for flour and most bread traits. Summarizing the results previously reported [8], flint hybrids had low water binding capacity, while it was high for waxy hybrids. Flint hybrids also had large onset pasting temperature, which was low for $w x 1$ hybrids, and the patterns of variability were similar for trough, breakdown and area under the curve. The $o 2$ hybrids had the highest maximum viscosity, which was low for $w x 1$ hybrids. The 02 hybrids had the highest values of final viscosity, which was low for the wx1 hybrids. Flint hybrids had low maximum viscosity and high final viscosity. Finally, the waxy hybrids had soft crumbs, low hardness and high cohesiveness, which was lowest for the flint hybrids. The wx1 hybrids had low chewiness and instant recovery speed. Garzón et al. [6] found that water binding capacity was lower for some typical flint than for some typical dent maize populations. Furthermore, flint populations had higher onset pasting temperature than dent populations [6]. Additionally, dent populations had higher maximum viscosity and final viscosity than flint populations [6]. In the previous article, some flints had lower flotation index, setback, crumb color $\mathrm{L}^{*}$ and chewiness than some dents. However, endosperm type had no significant effects on flour and bread quality, while geographical origin and growth cycle had significant differences for several quality traits. Therefore, other genetic and environmental factors seem to be involved in the rheological performance of maize genotypes.

Based on the correlations between nutrients, breeding for increasing protein or lipid content would not have expected correlated effects on other nutrients. Similarly, IgnjatovićMicić et al. [19] found that correlations between proteins and oil make some accessions suitable for simultaneous multi-trait improvement. Consequently, it should be possible to modify several mutants without undesirable effects on other nutrients.

Based on the regressions found here, modifying nutrients in maize would have substantial effects on the rheological properties of the flour, which implies that the behavior of the maize flour for bakery would be significantly affected by modifications of nutrients content. However, the effects of nutrient modifications on bread characteristics are very 
limited. Similarly, Mouliney et al. [20] showed that wx1 improved the bread quality in wheat or retard bread staling [21]. Carbas et al. [22], working with maize without these mutants, reported that high protein content was detected in varieties with higher breadability, and hypothesized that high protein content could induce increased amounts of flour water absorption ratio and corresponding higher bread moisture, as the crumb moisture was identified as a relevant attribute for the consumer acceptability of maize bread. Accordingly, Revilla et al. [8] reported that the mutant wx1 had large effects on rheological quality, and concluded that $w x 1$ can be used for improving maize bread quality, and the choice of the maize genotype could significantly affect the final results. GonzálezAmaro et al. [23] evaluated diverse Mexican maize landraces and found that those with diverse combinations of nutrients had variable rheological characteristics; for example, the landrace Zapalote had high protein and ash and low lipid, and produced masa with high pasting temperature and peak viscosity, low final viscosity and variable setback; Tuxpeño had low protein, ash and lipid, and its masa had medium pasting temperature and setback, low peak viscosity and high final viscosity; Chalqueño had medium protein and ash and low lipid and a masa with low pasting temperature, medium peak viscosity and setback, as well as high final viscosity. Conversely, the commercial hybrid used as check had high protein and lipid, and medium ash and yields a masa with low pasting temperature, peak viscosity, setback and vinal viscosity. Therefore, rheological performance was not clearly related to the content of any of the nutrients.

\section{Conclusions}

There was genetic diversity among endosperm types and genotypes for all nutrients, and flint hybrids had the highest protein and lipid content. The mutants 02 and $w x 1$ had significant effects in some hybrids, but those effects were not consistent across genotypes. The mutant 02 had no significant effects on nutrient content, the mutant $w x 1$ had significantly increased protein and reduced lipid, and both mutants reduced ash and starch content and increased total fiber. Protein and lipid can be improved independently; but further studies are need to delve deep into the relationships between agronomic performance, nutrient content and rheological factors, and to build appropriate breeding populations for overcoming the possible negative effects due to the increase of starch that causes selection for larger kernels.

Supplementary Materials: The following are available online at https:/ /www.mdpi.com/article/10 .3390 /agronomy11122509/s1, title, Table S1: Table S1. Mean squares from the combined analyses of variance of 13 maize hybrids with high amylopectin (waxy1) or protein (opaque2), and dent or flint kernel and in the four endosperms types evaluated during two years in two locations of Pontevedra (Northwestern Spain); Table S2: Table S2. Mean squares from the analyses of variance by endosperm types of 13 maize hybrids with high amylopectin (waxy1) or protein (opaque2), and dent or flint kernel and in the four endosperms types evaluated during two years in two locations of Pontevedra (Northwestern Spain).

Author Contributions: Conceptualization, P.R.; methodology, L.Á.-I. and R.G.; formal analysis, R.A.M. and P.R.; investigation, L.Á.-I. and R.G.; resources, P.R. and C.M.R.; writing-original draft preparation, L.Á.-I. and P.R.; writing - review and editing, P.R. and C.M.R.; and funding acquisition, P.R. and C.M.R. All authors have read and agreed to the published version of the manuscript.

Funding: This research was funded by the project Grant PID2019-108127RB-I00 (MCIU/AEI/FEDER, UE) Ministerio de Ciencia, Innovación y Universidades (MCIU), Agencia Estatal de Investigación (AEI) and Fondo Europeo de Desarrollo Regional (FEDER, EU)".

Data Availability Statement: Data are available from the authors upon request.

Conflicts of Interest: The authors declare no conflict of interest. 


\section{References}

1. Andorf, C.; Beavis, W.D.; Hufford, M.; Smith, S.; Suza, W.P.; Wang, K.; Woodhouse, M.; Yu, J.M.; Lubberstedt, T. Technological advances in maize breeding: Past, present and future. Theor. Appl. Genet. 2019, 132, 817-849. [CrossRef]

2. Brites, C.; Trigo, M.J.; Santos, C.; Collar, C.; Rosell, C.M. Maize-Based Gluten-Free Bread: Influence of Processing Parameters on Sensory and Instrumental Quality. Food Biop. Technol. 2010, 3, 707-715. [CrossRef]

3. De la Hera, E.; Talegon, M.; Caballero, P.; Gomez, M. Influence of maize flour particle size on gluten-free breadmaking. J. Sci. Food Agric. 2013, 93, 924-932. [CrossRef] [PubMed]

4. Landa, A.; Revilla, P.; Malvar, R.A.; Butrón, A.; Ordás, A. Maíz para panificación. Agricultura 2006, 886, 506-509.

5. Vaz Patto, M.C.; Moreira, P.M.; Carvalho, V.; Pego, S. Collecting maize (Zea mays L. convar. mays) with potential technological ability for bread making in Portugal. Gen. Res. Crop Evol. 2007, 54, 1555-1563. [CrossRef]

6. Garzón, R.; Rosell, C.M.; Malvar, R.A.; Revilla, P. Diversity among maize populations from Spain and the United States for dough rheology and gluten-free breadmaking performance. Int. J. Food Sci. Technol. 2017, 52, 1000-1008. [CrossRef]

7. Berardo, N.; Mazzinelli, G.; Valoti, P.; Laganà, P.; Redaelli, R. Characterisation of maize germplasm for the chemical composition of the grain. J. Agri. Food Chem. 2009, 57, 2378-2384. [CrossRef] [PubMed]

8. Revilla, P.; Garzon, R.; Rosell, C.M.; Malvar, R.A. Effects of high amylopectin (waxy1) and high-quality protein (opaque2) maize mutants in agronomic performance and bakery quality. J. Cereal Sci. 2019, 89, 102796. [CrossRef]

9. Xiaoyang, W.; Dan, C.; Yuqing, L.; Weihua, L.; Xinming, Y.; Xiuquan, L.; Juan, D.; Lihui, L. Molecular characteristics of two new waxy mutations in China waxy maize. Mol. Breed. 2017, 37, 27. [CrossRef]

10. Lu, D.; Lu, W. Effects of protein removal on the physico-chemical properties of waxy maize flours. Starch/Starke 2012, 64, 874-881. [CrossRef]

11. Bao, J.D.; Yao, J.Q.; Zhu, J.Q. Identification of glutinous maize landraces and inbred lines with altered transcription of waxy gene. Mol. Breed. 2012, 30, 1707-1714. [CrossRef]

12. Vasal, S.K. High quality protein corn. In Specialty Corns; Hallauer, A.R., Ed.; CRC Press: Boca Raton, FL, USA, $1994 ;$ pp. 80-121.

13. Mertz, E.T.; Bates, L.S.; Nelson, O.E. Mutant gene that changes protein composition and increases lysine content of maize endosperm. Science 1964, 145, 279-280. [CrossRef] [PubMed]

14. Lawton, J.W.; Wilson, C.M. Proteins of the kernel. In Corn: Chemistry and Technology, 2nd ed.; White, P.J., Johnson, L.A., Eds.; American Association of Cereal Chemists Inc.: St. Paul, MN, USA, 2003; pp. 313-354.

15. SAS Institute. SAS Version 9.3; The SAS Institute: Cary, NC, USA, 2010.

16. Alves, M.L.; Brites, C.; Paulo, M.B.; Carbas, B.; Belo, M.; Mendes-Moreira, P.; Brites, C.; Bronze, M.R.; Gunjača, J.; Šatović, Z.; et al. Setting up decision-making tools towards a quality-oriented participatory maize breeding program. Front. Plant Sci. 2019, 8, 2203. [CrossRef] [PubMed]

17. Vaz Patto, M.C.; Alves, M.L.; Almeida, N.F.; Santos, C.; Mendes Moreira, P.; Satovic, Z.; Brites, C. Is the bread making technological ability of Portuguese traditional maize landraces associated with their genetic diversity? Maydica 2009, 54, $297-311$.

18. Dado, R.; Beek, S. In vitro ruminal starch digestibility in opaque-2 and regular corn hybrids. An. Feed Sci. Technol. 1998, 73, 151-160. [CrossRef]

19. Ignjatović-Micić, D.; Kostadinović, M.; Božinović, S.; Anđelković, V.; Vančetović, J. High grain quality accessions within a maize drought tolerant core collection. Sci. Agric. 2014, 71, 402-409. [CrossRef]

20. Mouliney, M.; Lavery, B.; Sharma, R.; Jenner, C. Waxy durum and lipid differ in their actions as improvers of bread quality. J. Cereal Sci. 2011, 54, 317-323. [CrossRef]

21. Hug-Iten, S.; Escher, F.; Conde-Petit, B. Staling of bread: Role of amylose and amylopectin and influence of starch-degrading enzymes. Cereal Chem. 2003, 80, 654-661. [CrossRef]

22. Carbas, B.; Vaz Patto, M.C.; Bronze, M.R.; Bento da Silva, A.; Trigo, M.J.; Brites, C. Maize flour parameters that are related to the consumer perceived quality of 'broa' specialty bread. Food Sci. Technol. 2016, 36, 259-267. [CrossRef]

23. González-Amaro, R.-M.; Figueroa, J.-D.-C.; Perales, H.; Véles-Medina, J.J. Physicochemical and Nutritional Properties of Different Maize Races on Toasted Tortillas. Cereal Chem. 2017, 94, 451-457. [CrossRef] 